\title{
Influence of water fluctuations on the limnological characteristics of two floodplain lagoons (Ribeira do Iguape Valley, state of Sáo Paulo, Brazil)
}

Influência da variação do nível d'água sobre características limnológicas de duas lagoas de planície de inundação (Vale do Ribeira do Iguape, São Paulo, Brazil)

Rogério Herlon Furtado Freire ${ }^{1}$, Roseli Frederigi Benassi ${ }^{2 *}$, Maria do Carmo Calijuri ${ }^{3}$ and

Aline Alves Sanchez $z^{2}$

${ }^{1}$ Universidade Federal do ABC - UFABC, Avenida dos Estados, 5001, Bloco A, 6º andar, Bangu, CEP 09210-580, SantoAndré, SP, Brasil

e-mail: rogerioherlon@gmail.com

${ }^{2}$ Centro de Engenharia, Modelagem e Ciências Sociais Aplicadas - CECS, Universidade Federal do ABC - UFABC, Avenida dos Estados, 5001, Bloco A, $6^{\circ}$ andar, Bangu, CEP 09210-580, Santo André, SP, Brasil e-mail: roseli.benassi@ufabc.edu.br

${ }^{3}$ Departamento de Engenharia Hidráulica e Sanitária - SHS, Escola da Engenharia de São Carlos - EESC, Universidade de São Paulo - USP, Avenida Trabalhador São Carlense, 400, CP 359,

CEP 13566-590, São Carlos, SP, Brasil

e-mail: calijuri@sc.usp.br

\begin{abstract}
Aim: Current study assessed the influence of hydrometric levels on the limnological characteristics of two river floodplain systems in the Ribeira do Iguape Basin (state of São Paulo, Brazil). Methods: Rainfall data were collected daily from an automatic weather station in Jacupiranga SP Brazil and daily hydrometric level records were obtained from automatic linigraphs installed on the two adjacent rivers. Moreover, $\mathrm{pH}$, electrical conductivity and dissolved oxygen were measured by a multiparametric probe. Water samples were collected to analyze nitrate, ammoniac nitrogen, total nitrogen and phosphorus, total alkalinity and suspended material. The samplings were carried out in April and July, representative months for low and high water periods, respectively. Results and Conclusions: Statistical analysis highlighted the "effect of homogenization", attributed to the hydrological pulses in several studies carried out in river-floodplain systems. This effect in current study was more underscored at Lagoon 2, which remained connected for a longer period with the adjacent river, when compared to Lagoon 1- River Jacupiranguinha system. Higher dissolved oxygen concentrations at Lagoon 2, in contrast with the Lagoon 1 featuring anoxia during the whole period under analysis, were also attributed to the above-mentioned greater hydrological connectivity. Current study highlights that the water-mediated transferences during the high water period may contribute not only towards the fertilization of marginal lagoons (inputs of nutrients and organic matter) but also to significant pollutant loads, according to land use along the watersheds. In the case of Lagoon 1- River Jacupiranguinha system, even though further studies are needed and strongly recommended, it is reasonable to assume that the discharges of mining effluents into the river may result in ecological damage not only to the receiving water body but also to the connected ecosystems.
\end{abstract}

Keywords: lagoons; flood plain rivers; hydrometric levels; hydrological connectivity; physical and chemical characteristics.

Resumo: Objetivo. O objetivo deste trabalho foi avaliar a influência da variação dos níveis hidrométricos sobre as características limnológicas de dois sistemas de rio-planície localizados na Bacia do Ribeira do Iguape (São Paulo - SP). Material e Métodos. Dados diários de precipitaçáo foram obtidos a partir de uma estaçáo instalada na cidade de Jacupiranga, enquanto registros diários de níveis hidrométricos foram obtidos de linígrafos automáticos instalados nos respectivos rios. Medidas de $\mathrm{pH}$, condutividade elétrica e oxigênio dissolvido foram realizadas com sonda multiparâmetros. Amostras de água foram coletadas para análise de nitrato, nitrogênio amoniacal, nitrogênio total, fósforo 
total, alcalinidade e material em suspensão. As amostras foram coletadas em abril e julho, meses representativos dos períodos de águas altas e baixas, respectivamente. Resultados e Conclusáo. A análise estatística dos dados evidenciou o "efeito de homogeneizaçáo", atribuído aos pulsos hidrológicos em outras pesquisas realizadas em sistemas rios-planícies de inundação. Em nosso estudo, este efeito foi mais evidente na Lagoa 2, a qual permaneceu mais tempo conectada ao rio adjacente quando comparada ao sistema Lagoa 1-Rio Jacupiranguinha. As maiores concentrações de oxigênio dissolvido observadas na Lagoa 2, em comparação com a Lagoa 1, anóxica durante o período de estudo, também foi atribuída à sua maior conectividade hidrológica. O estudo também mostrou que as transferências mediadas pela água durante o período de águas altas pode contribuir náo somente para a fertilização das lagoas marginais (entrada de nutrientes e matéria orgânica), mas também para o aporte de cargas poluidoras, dependendo do uso do solo ao longo das bacias de drenagem. No caso do sistema Lagoa 1-Rio Jacupiranguinha, embora estudos posteriores sejam necessários, é razoável assumir que as descargas de efluentes de mineração podem resultar em prejuízos ecológicos não somente ao corpo d'água receptor, mas também aos ecossistemas conectados.

Palavras-chave: lagoas; rios de planície de inundação; níveis hidrométricos; conectividade hidrológica; características físicas e químicas.

\section{Introduction}

According to Pringle (2001), hydrological connectivity should be understood as the transfer process of mass, energy and/or organisms transfer process within or between elements of the hydrological cycle. In a broader sense, it represents a moment of interconnection between landscape morphological elements and material flows throughout the drainage basin (Bracken \& Croke, 2007). Applying this concept to river-floodplain systems, hydrological pulses are known as the main connectivity factor between adjacent aquatic ecosystems, defining the temporal variability of the limnological characteristics in marginal lagoons, influencing the input of nutrients, organic matter and its production and respiration rates (Neiff et al., 2001; Mitsch \& Gosselink, 2007; Thomaz et al., 2007b). Depending on geomorphological and topographical factors and on the rainfall regime, marginal lagoons may have different degrees of connection to the adjacent channels. It is actually a peculiarity that contributes towards the heterogeneity of aquatic habitats and the maintenance of high species diversity generally observed in these environments (Henry, 2005; Neiff, 1990; Neiff, 2001; Junk et al., 1989). Moreover, the intensity and duration of rainfall, land use patterns and vegetation cover are considered intervening factors in the degree of lateral connectivity between the river-floodplain systems (Bracken \& Croke, 2007; Brooks, 2003; Pringle, 2001; Rocha \& Thomaz, 2004). Although wetlands provide many environmental services and contribute towards the survival of millions of people around the world, they are among the most globally impacted ecosystems due to pressure from agricultural and industrial activities, urbanization, and structures for the managing of water resources, which cause changes in their flow regimes (Barliwa, 1995; Jong et al., 2015; Kansiime et al. 2007; Rebelo et al. 2010). In the Ribeira Valley region (São Paulo, Brazil), aquatic ecosystems have been submitted to an increasing pressure from anthropic activities, represented mainly by agriculture, industrial and mining activities, in addition to impacts caused by the discharge of domestic and industrial effluents (Benassi et al., 2012; Cunha et al., 2010). Since actions for environmental quality management of wetlands in river-floodplain systems should be supported by conservation plans, on a basin scale, that include actions involving scientific knowledge integrated to ecological and socio-economic aspects (Clare et al., 2011; Margules \& Pressey, 2000), current study investigates changes in the limnological characteristics of two lagoons in neighboring river basins in response to variations in hydrometric levels of the adjacent rivers.

\section{Material and Methods}

\subsection{Study area}

The Ribeira do Iguape Basin lies between 233' and $25^{\circ} 30^{\prime} \mathrm{S}$ and $46^{\circ} 50^{\prime}$ and $50^{\circ} 00^{\prime} \mathrm{W}$, covering an area of $28,306 \mathrm{~km}^{2}, 61 \%$ of which in the state of São Paulo and 39\% in the state of Paraná (Brazil). The basin has a prolonged conformation on a SWNE direction, closely parallel to the oceanfront (Figure 1). According to Cunha et al. (2010), the Ribeira do Iguape River Basin shelters remnant fragments of the Atlantic Tropical Rain Forest and 


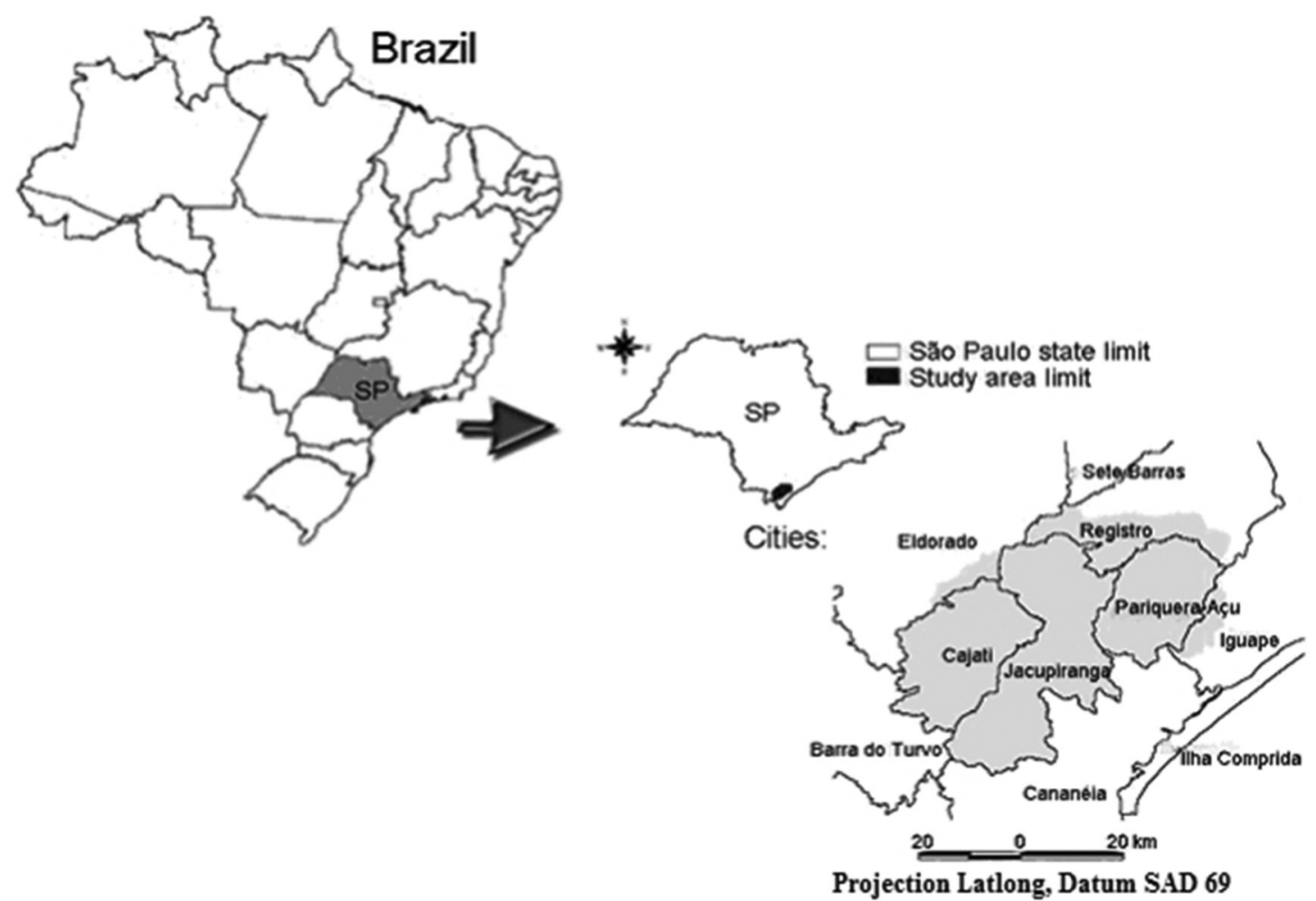

Figure 1. Geographical location of Ribeira do Iguape Valley (São Paulo, Brazil).

is thus considered a strategic ecological region, even though there is a degradation caused by a continuous process of natural resources due to urban expansion, deforestation for the development of agricultural and industrial activity. Two systems were selected in current study: River Jacupiranguinha - Lagoon 1 and River Jacupiranga - Lagoon 2. The two lagoons are inserted in the floodplains and, therefore, they undergo periodic flooding. Lagoon 1 is situated about 2,000 $\mathrm{m}$ from the urban perimeter of Cajati (Figure 2a), the main town in the River Jacupiranguinha sub-basin, whereas Lagoon 2, inserted in the sub-basin of the River Jacupiranga River, is about $4,000 \mathrm{~m}$ from the town of Jacupiranga (Figure 2b). About $90 \%$ of the domestic effluents produced by the two towns are collected but only approximately $65 \%$ of the total is treated by the respective stabilization pond systems (Australian configuration). Although stabilization ponds have been considered the most economically feasible alternative for wastewater treatment in Ribeira do Iguape Basin, their effluents may cause significant inputs of nitrogen and phosphorus to the receiving water bodies (Calijuri et al., 2008). Regarding to land use, the surroundings of Lagoon 1 - River Jacupiranguinha are mainly characterized by banana plantations, pasture and deforested areas on the two sides of the river, with scanty original vegetation.
Besides receiving effluents from a stabilization pond system (about 1,000 m upstream to Lagoon 1), the river Jacupiranguinha is also submitted to high pollutant loads from the discharge of non-treated mining effluents (see the mining waste reservoir in Figure 2a). The surrounding area of Lagoon 2 is dominated by tea cropping, pasture areas (buffalo), as well as small and medium sized grass and vegetation. The lagoon lies further from the main urban nucleus and from the stabilization ponds system when compared to Lagoon 1. Although the surroundings of Lagoon 2 are more preserved, some points of clandestine sewage discharges have been observed in the upstream sections of the river Jacupiranga. According to Köppen's classification, the climate of the studied area is Cfa, or rather, humid subtropical climate with hot summers. Most rainfall occurs between November and April (with peaks often observed during the Jan-Feb-Mar trimester), while the dry period goes from May to September or October.

\subsection{Sampling}

Samplings were carried out in two distinct hydrological periods, called low and high-water periods, represented by April and June, respectively, throughout this paper. In the case of Lagoon 1 - River Jacupiranguinha system (eight points), 
the samples were collected in 2005, whereas data for the Lagoon 2 - River Jacupiranga system were obtained in 2007. Water temperature, dissolved oxygen (DO) and electrical conductivity (EC) were measured at regular intervals of $10 \mathrm{~cm}$ throughout the vertical profiles, from the subsurface to the near bottom sediments, by a previously calibrated multiparameter probe (Yellow Spring 556 MPS Multisond). Subsurface water samples were collected for the analysis of nitrate $\left(\mathrm{N}-\mathrm{NO}_{3}^{-}\right)$, ammoniacal nitrogen $\left(\mathrm{N}-\mathrm{NH}_{4}^{+}\right)$, total nitrogen and phophorus, alkalinity and suspended material (including fractioning). Samples were kept at $-4.0^{\circ} \mathrm{C}$ until analysis. Chemical analyses were performed
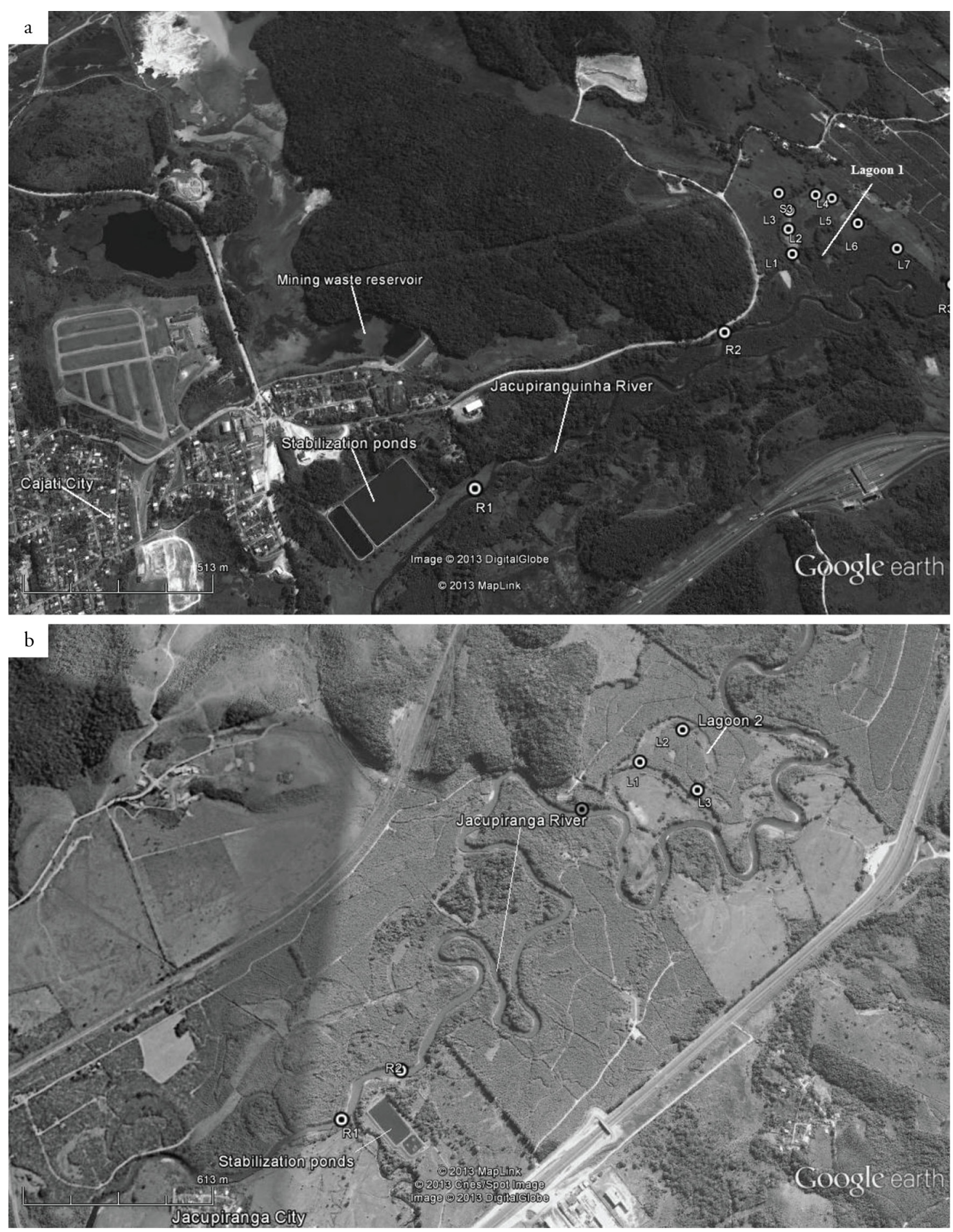

Figure 2. Overview of floodplain ecosystems studied with the respective sampling sites: (a) Lagoon 1 - Jacupiranguinha River and (b) Lagoon 2 - Jacupiranga River. Source: Google Earth, accessed in August/2013. 
according to APHA (2005). Daily rainfall data were retrieved from an automatic weather station installed in the town of Jacupiranga (Code F4-017; altitude: $90 \mathrm{~m}$; $24^{\circ} 43^{\prime} \mathrm{S}$; $48^{\circ} 01^{\prime} \mathrm{W}$ ), whereas daily records of hydrometric levels were retrieved from automatic linigraphs ( $\& \& S^{\circledast}$ Model LI3050) installed on the two rivers, close to the lagoons.

It is noteworthy that, in both study periods, the sampling frequency was defined based not only on research objectives, but also on financial and logistical constraints, which also determined the number of collected samples.

\subsection{Data analysis}

The dataset was submitted to the Principal Component Analysis (PCA) i) to reduce data dimensionality and verify the association between the investigated variables and ii) to observe a possible differentiation between the investigated river-floodplain systems. PCA results were interpreted by examining the projection of plots of the extracted factors on the factorial plane formed with statistically significant axes (Legendre \& Legendre, 1998). All statistical analyses were performed with STATISTICA (Statsoft Inc., 2011).

\section{Results and Discussion}

Figure 3 shows the daily rainfall rates, representative of rainfall over the two catchment areas. Historically, the rainy period goes from October to March, with rain peaks frequently occurring during the Jan-Feb-March trimester. Data on Lagoon 1- River Jacupiranguinha system (Figure 3a), collected between October 2004 and July 2005, were more representative of this general trend, whereas data for Lagoon 2 - River Jacupiranga (Figure $3 \mathrm{~b}$ ), corresponding to the period between
December 2006 and July 2007, presented also rain peaks in July, which, although historically within the dry period, presented a mean rainfall rate twice higher than the historical mean for this month. The space-time variability of rainfall has an important role in understanding the ecological dynamics of river-floodplain systems, since they are determinant to the hydrological pulse regime, which delimits different environmental scenarios during the year (Krusche \& Mozeto, 1999; Bracken \& Croke, 2007).

In this study, the rainfall influence on the hydrological dynamics of the two rivers was verified. However, the correlation between rainfall and hydrometric levels was more pronounced for the River Jacupiranguinha (Lagoon 1; r: 0.54, $\mathrm{n}: 156, \mathrm{p}<0.05)$, although the same tendency of positive correlation had been observed for the River Jacupiranga (Lagoon 2) shows the hydrometric levels together with the respective overflowing lines. Both datasets showed a large variability, with the highest rates registered during the rainy period and some peaks in July for the River Jacupiranga. Analyzing the topographic profiles and hydrometric levels, as well as in situ observations, the spatial and temporal dynamics of connectivity for both river-floodplain systems could be followed. Integrated data showed that at the hydrometric level of $2.74 \mathrm{~m}$, Lagoon 1 received the first inflows from the River Jacupiranguinha (near point 4), while a condition of complete lateral connectivity was observed at $2.97 \mathrm{~m}$ (some days in January and May; Figure 4a). In the case of Lagoon 2 - River Jacupiranga system (Figure 4b), a complete connectivity was possible at a river level of $1.50 \mathrm{~m}$. The above condition was observed during most of the rainy period and some days in May and July 2007. Therefore, although the
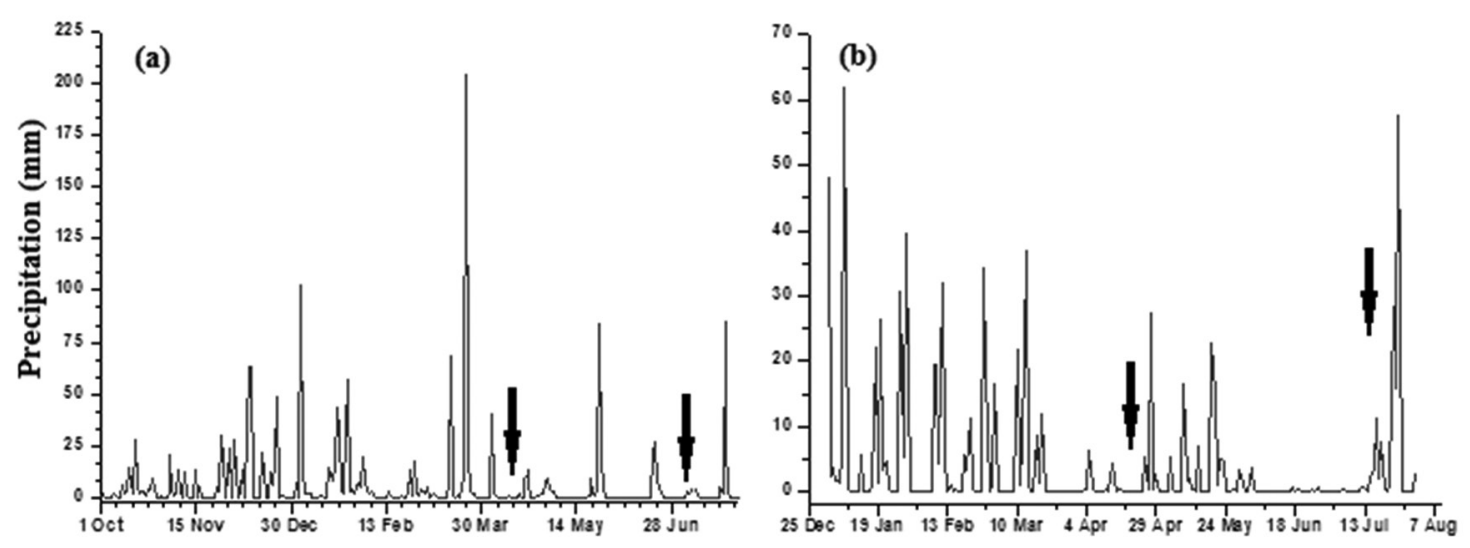

Figure 3. Daily rainfall corresponding to the two rivers-floodplains systems studied: (a) Lagoon 1 - Jacupiranguinha River and (b) Lagoon 2 - Jacupiranga River. The arrows indicate the approximate dates of sampling. 

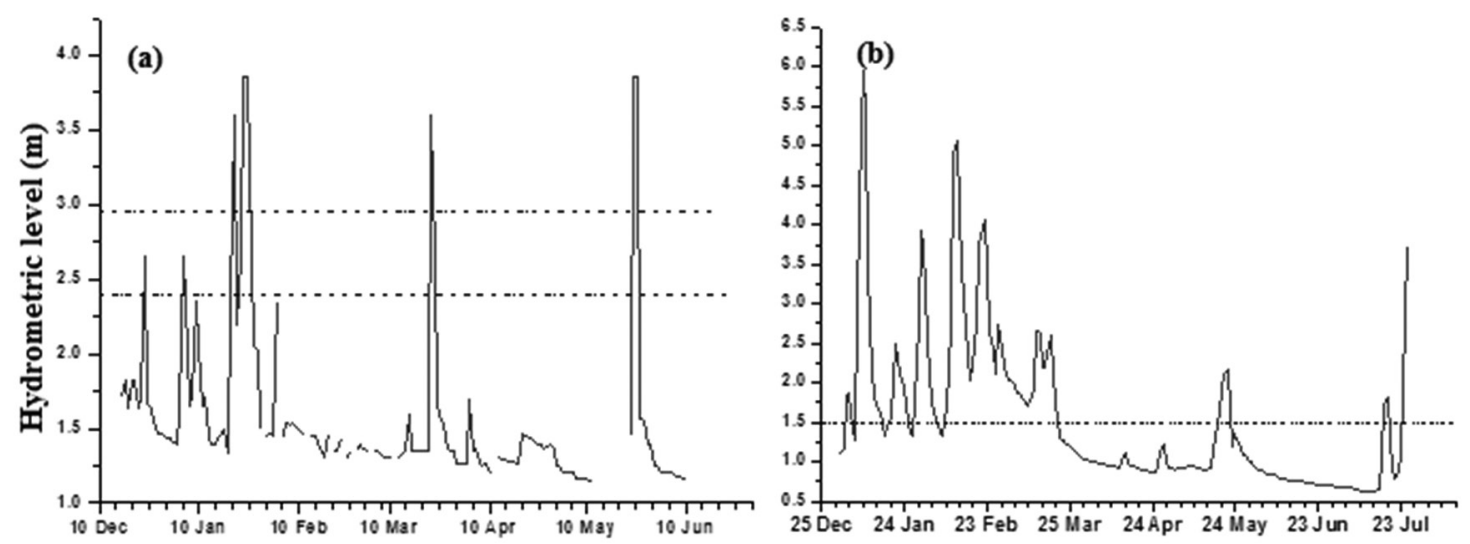

Figure 4. Temporal variability of the hydrometric levels for the (a) Jacupiranguinha River, between December/04 and May/05, and for the (b) Jacupiranga River, between December/06 and July/07. Overflowing level is indicated by dashed straight lines.

Lagoon 2 did not have a permanent connection with the River Jacupiranga, the system remained connected during a significant part of the year, in contrast to what was observed in Lagoon 1 - River Jacupiranguinha. Regarding morphometry, the two lagoons are shallow environments, with mean depths lower than $3.0 \mathrm{~m}$ even during the high-water period. Lagoon 1, which remained disconnected from the River Jacupiranguinha during most part of the year, reached a depth below $1.5 \mathrm{~m}$ during the low-water period. This condition may have important ecological implications, since shallow environments favor a greater contact between overlaying waters and bottom sediments. Within the context, it is essential to highlight the role of hydrological connectivity as a key process in river floodplains since it is directly involved with the transference of matter, energy and organisms among the environments of riverine corridors (Tockner et al., 2000; Pringle, 2003). This fact gains greater importance when the increasing anthropogenic pressures, mainly represented by urban expansion, deforestation for agriculture, mining and industrial activities, on the aquatic ecosystems at the Ribeira do Iguape Valley are taken into account. All these factors interfere either on the amplitude and periodicity of the hydrological pulses or on the space-time variability of the limnological variables. Therefore, knowledge on the role of the connectivity in water-mediated transference of pollutant loads (nutrients, sediments, organic matter and persistent contaminants) to the floodplain lagoons in strongly impacted watersheds during the high-water periods is fundamental to their management (Hein et al., 2003; Pringle, 2001; Tockner et al., 1999).
The Table 1 shows the mean rates of the abiotic variables investigated for both river-floodplain systems.

The PCA performed on the dataset returned three main statistically significant axes. However, for interpretation purposes, the factorial plan formed by the two first axes was taken into account, which explained $57.42 \%$ of total data variability (Table 1 ).

Table 2 shows Pearson's correlation coefficients between variables and axes 1 and 2 . The factorial plan in Figure 5 highlighted the formation of the two main groupings, which were considered good representative of the Lagoon 1 - River Jacupiranguinha and Lagoon 2 - River Jacupiranga systems. When only the two lagoons (designated by L1 and L2) are considered, the greater proximity among the samples corresponding to Lagoon 2 was a strong indicative of a lower spatial heterogeneity in this environment. Several studies carried out in river-floodplain systems have demonstrated a homogenization effect caused by floods at different spatial extents (Thomaz et al., 1997; Bonecker et al., 1998; Lewis Junior et al., 2000; Tockner et al., 2000). According to Thomaz et al. (2007a), this effect is observed not only in relation to chemical and physical factors, but also in aquatic communities in terms of turnover and beta diversity decrease. Due to the representativeness of several studies carried out in different spatial scales, Thomaz et al. (2007a) have suggested that the "homogenization of habitats" following floods may be considered a general pattern in river-floodplain systems.

The examination of Figure 5 and the contribution of the variables for the construction of axes 1 and 2 evidence that DO and LEV are the 
Table 1. Mean values ( \pm standard deviation) for the abiotic variables in the lagoons and adjacent rivers.

\begin{tabular}{|c|c|c|c|c|c|c|c|c|}
\hline & \multicolumn{2}{|c|}{ Lagoon 1} & \multicolumn{2}{|c|}{ Jacupiranguinha River } & \multicolumn{2}{|c|}{ Lagoon 2} & \multicolumn{2}{|c|}{ Jacupiranga River } \\
\hline & High water & Low water & High water & Low water & High water & Low water & High water & Low water \\
\hline $\mathrm{pH}$ & \pm 0.10 & & & & $6.4 \pm 0.3$ & $6.2 \pm 0.1$ & $6.6 \pm 0.1$ & $6.5 \pm 0.3$ \\
\hline $\mathrm{EC}\left(\mu \mathrm{Scm}^{-1}\right)$ & $2 \pm 7.80$ & $488 \pm 8.9$ & $1 \pm 78$ & $960 \pm 80$ & $6 \pm 5.6$ & $137 \pm 17$ & $182 \pm 8.9$ & $139 \pm 42$ \\
\hline $\mathrm{DO}\left(\mathrm{mgO}_{2} \mathrm{~L}^{-1}\right)$ & $0.49 \pm 0.20$ & $1.14 \pm 0.2$ & $5.27 \pm 1.5$ & $2.93 \pm 0.63$ & $3.78 \pm 1.8$ & $6.27 \pm 0.3$ & $7.13 \pm 0.3$ & $8.03 \pm 0.3$ \\
\hline $\mathrm{T}\left({ }^{\circ} \mathrm{C}\right)$ & $23.7 \pm 0.10$ & $16.5 \pm 0.7$ & $23.0 \pm 0.3$ & $18.3 \pm 0.5$ & $26.0 \pm 0.1$ & $18.3 \pm 0.1$ & $25.9 \pm 0.4$ & $18.4 \pm 0.1$ \\
\hline $\begin{array}{l}\text { Alk } \\
\left(\text { meqCaCO } \mathrm{L}^{-1}\right)\end{array}$ & $75.4 \pm 18.3$ & $63.58 \pm 0.1$ & $38.8 \pm 2.2$ & $46.18 \pm 3.1$ & $50.0 \pm 7.8$ & $48.8 \pm 2.5$ & $51.5 \pm 0.7$ & $78.2 \pm 41$ \\
\hline TSS (mgL-1) & $12.51 \pm 5.15$ & $32.52 \pm 29.06$ & & $11.95 \pm 0.92$ & $13.09 \pm 4.86$ & $24.37 \pm 11.96$ & $52.84 \pm 6.13$ & $10.55 \pm 3.18$ \\
\hline ISS (mgL-1) & $6.05 \pm 2.64$ & $4.00 \pm 5.88$ & $2.53 \pm 0.78$ & $7.75 \pm 6.86$ & $0.01 \pm 0.00$ & $18.47 \pm 8.94$ & $41.40 \pm 9.76$ & $7.85 \pm 2.62$ \\
\hline OSS $\left(\mathrm{mgL}^{-1}\right)$ & $6.46 \pm 3.09$ & $22.82 \pm 14.31$ & $1.93 \pm 0.61$ & $4.20 \pm 5.94$ & $13.08 \pm 4.85$ & $5.90 \pm 3.32$ & $11.42 \pm 3.66$ & $2.70 \pm 0.56$ \\
\hline $\mathrm{N}-\mathrm{NO}_{3}\left(\mathrm{mgL}^{-1}\right)$ & $1.32 \pm 0.40$ & $1.06 \pm 0.2$ & $0.51 \pm 0.1$ & $0.49 \pm 0.4$ & $0.53 \pm 0.0$ & $0.05 \pm 0.0$ & $0.48 \pm 0.1$ & $1.04 \pm 0.3$ \\
\hline $\mathrm{N}-\mathrm{NH}_{4}\left(\mathrm{mgL}^{-1}\right)$ & $0.24 \pm 0.06$ & $0.36 \pm 0.13$ & $0.34 \pm 0.01$ & $0.34 \pm 0.13$ & $0.34 \pm 0.24$ & $0.44 \pm 0.27$ & $0.51 \pm 0.36$ & $2.18 \pm 3.91$ \\
\hline $\mathrm{TN}\left(\mathrm{mgL}^{-1}\right)$ & $1.15 \pm 0.10$ & $1.49 \pm 0.3$ & $2.21 \pm 1.8$ & $1.75 \pm 0.67$ & $1.36 \pm 0.7$ & $2.80 \pm 1.2$ & $1.77 \pm 04$ & $5.6 \pm 5.1$ \\
\hline TP (mgL-1) & $2582 \pm 2110$ & $1849 \pm 1.6$ & $189 \pm 70$ & $37327 \pm 51725$ & $2.20 \pm 0.8$ & $5464 \pm 17$ & $6.74 \pm 0.5$ & $3.85 \pm 0.8$ \\
\hline
\end{tabular}

Table 2. Pearson correlation coefficients between the abiotic variables and the principal components considered for interpretation.

\begin{tabular}{clcc}
\hline & \multicolumn{1}{c}{ Variables } & Component 1 (33.26\%) & Component 2 (24.16\%) \\
\hline TP & Total phosphorus & 0.398 & 0.103 \\
TN & Total nitrogen & -0.693 & -0.114 \\
NIT & Nitrate & 0.075 & -0.927 \\
AMON & Ammoniacal nitrogen & -0.613 & -0.241 \\
pH & Hydrogenionical potential & 0.678 & -0.273 \\
EC & Eletrical condutivity & 0.780 & -0.212 \\
DO & Dissolved oxygen & -0.626 & 0.644 \\
ALK & Total alkalinity & -0.182 & -0.651 \\
ISS & Inorganic suspended solids & -0.642 & -0.353 \\
OSS & Organic suspended solids & -0.357 & -0.588 \\
LEV & Hydrometric level & -0.738 & 0.471 \\
\hline
\end{tabular}

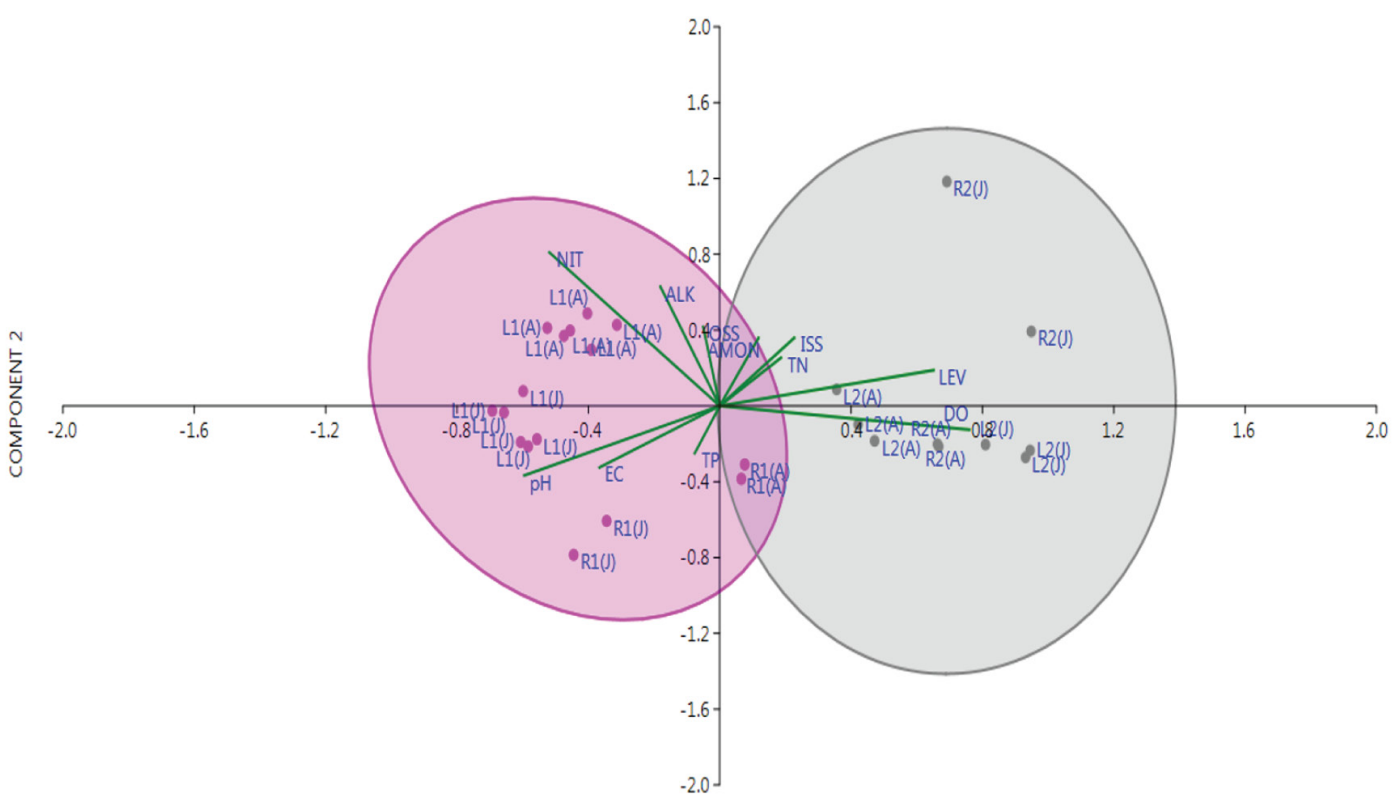

COMPONENT 1

Figure 5. Biplot of a Principal Component Analysis (PCA) showing the two first axes. The points located at the Lagoons and adjacent rivers were designate by the capital letters "L" and "R" (L1: marginal lagoon to the Jacupiranguinha River, R1; L2: marginal lagoon to the Jacupiranga River, R2), while the sampled months (April and July) were designated by the capital letters "A" and "J". 
main responsible for grouping Lagoon 2 - River Jacupiranga samples. High OD concentrations in Lagoon 2 may be attributed to two main factors: i) greater rates of water renewal, since it remained connected with more oxygenated waters (River Jacupiranga) during practically all the rainy period and also during some days in May and July 2007, and ii) a scenario of low anthropogenic pressure when compared to that of the system Lagoon 1 - River Jacupiranguinha, which, besides being closer to the main urban nucleus, receives discharges from the stabilization pond treatment system and the non-treated mining effluents. Moreover, the low connectivity between the Lagoon 1 and River Jacupiranguinha may be considered a critical factor for the development of anoxia in the lagoon, since the inputs of more oxygenated waters from the river was limited to only a few days during 2005 . Investigating changes in abiotic characteristics of three lateral lagoons in the Paranapanema River (São Paulo, Brazil), Granado \& Henry (2012) observed high DO rates for connected lagoons when compared to Cavalos Lagoon, which remained isolated during the research period. The development of anoxia, including the formation of well-shaped oxyclines, characterized Lagoon 1 as a chemically reduced environment. This status may have a significant influence on the magnitude of fluxes (bottom-up) that take place in the water-sediment interface. Still with respect to the PCA, the representative sample of the grouping Lagoon 1 - River Jacupiranguinha was discriminated mainly by the variables $\mathrm{EC}, \mathrm{pH}, \mathrm{ALK}$ and NIT. In the case of EC, the abnormally high rates observed for point 2 (River Jacupiranguinha, upstream the lagoon) were attributed to the discharge of effluents from an industrial complex that processes apatite and carbonatite used in fertilizers, animal food and cement production, with high rates for the variables $\mathrm{pH}$ and ALK. In the case of nutrients, the concentrations of nitrogen and phosphorus (total and dissolved fractions) for both rivers strongly indicated inflows from these environments during the connectivity periods which may be a determinant factor for the sediment enrichment and lagoons eutrophication. Since hydrological pulses are the main driving force, materials (e.g. nutrients and suspended sediments) are transported from the river to the floodplain as well as from the floodplain to the river (e.g. organic detritus and algal biomass), establishing a complex dynamic of exchanges (Tockner et al., 1999). Regarding the river-floodplain systems under analysis, particularly for the system Lagoon 1 - River Jacupiranguinha, which receives pollutant loads from mining effluents, it is reasonable to suppose that water-mediated transference may input significant quantities of contaminants to the lagoon.

In a comparative study on the influence of land use on the water quality of rivers located in the Ribeira do Iguape Basin and submitted to different degrees of anthropogenic pressure, Cunha et al. (2010) observed higher total suspended solids (TSS) concentrations in River Jacupiranguinha when compared to the Rivers Canha and Pariquera-Açu. The authors associated this characteristic to the lack of riparian forest on both sides of the River Jacupiranguinha, which was also described by Moccellin et al. (2009). In current study, the highest TSS concentrations for Lagoon 1 - River Jacupiranguinha system was observed during the high-water period (April 2005), whereas the highest values for the River Jacupiranga corresponded to the July 2007 samples, or rather, the historically low-water period. This unexpected result was attributed to the occurrence of rainfall peaks a few days before sampling which contributed to the leaching of the watershed and, consequently, to the high ISS rates reported. The greatest OSS concentrations in the marginal lagoons reinforced their importance as producers and potential exporters of organic matter to the adjacent rivers.

Although results are from data collected on different years and in river-floodplain ecosystems in neighboring basins, they showed the importance of flood pulses and hydrological connectivity to the spatial and temporal variability of the limnological variables studied. In this context, the influence of the hydrological pulses and of water level variation on the lagoon dynamics was observed both temporally, with differentiation between periods of low and high-water, and spatially, when the lagoons presented different connectivity patterns. The study also confirmed the importance of hydrological connectivity as an ecological process of matter and energy transfer between river-plain ecosystems. Furthermore, since the two watersheds undergo anthropic impacts, such as unplanned urbanization, industrial activities and replacement of original vegetation cover, it is recommended that future studies should investigate the contamination degree of water, sediment and aquatic biota. It is important to take into account that the bottom sediments may become a potential diffused source of contaminants through their gradual release even after disabling the primary sources of pollution. 
The accumulation of trace metals, for instance, may lead to severe ecological implications.

Finally, it is essential that research and scientific knowledge on the functioning of wetlands is stimulated and disseminated to serve as a basis for integrated management actions aiming at the conservation of these areas and ensuring the maintenance of their numerous environmental services for local communities and society.

\section{Acknowledgements}

Financial support from Fundação de Amparo à Pesquisa no Estado de São Paulo - FAPESP (Processes 02/13449-1, 03/03859-0, 04/02274-1 and 2013/15392-1) and Conselho Nacional de Desenvolvimento Científico e Tecnológico - CNPq (CTHidro, Process $151371 / 2007-5)$ is gratefully acknowledged. The authors would like also to thank to SABESP for the availability of climatic data.

\section{References}

AMERICAN PUBLIC HEALTH ASSOCIATION APHA. Standard methods for examination of water and wastewater. Washington: APHA, 2005.

BARLIWA, J.S. The Lake Victoria environment: its fisheries and wetlands: a review. Wetlands Ecology and Management, 1995, 3(4), 209-224.

BENASSI, R.F., FREIRE, R.H.F. and CALIJURI, M.C. Space-temporal dynamics of limnological variables in a floodplain wetland located at Ribeira do Iguape Valley (São Paulo) at different hydrological periods. Acta Limnologica Brasiliensia, 2012, 24(1), 83-96. http://dx.doi.org/10.1590/S2179975X2012005000028.

BONECKER, C.C., LANSAC-TÔHA, F.A. and ROSSA, D. Planktonic and non-planktonic rotifers in two environments of the Upper Paraná River floodplain, State of Mato Grosso do Sul, Brazil. Brazilian Archives of Biology and Technology, 1998, 41(4), 447-456.

BRACKEN, L.J. and CROKE, J. The concept of hydrological connectivity and its contribution to understanding runoff-dominated geomorphic systems. Hydrological Processes, 2007, 21(13), 17491763. http://dx.doi.org/10.1002/hyp.6313.

BROOKS, C.P. A scalar analysis of landscape connectivity. Oikos, 2003, 102(2), 433-439. http://dx.doi. org/10.1034/j.1600-0579.2003.11511.x.

CALIJURI, M.C., CUNHA, D.G.F., QUEIROZ, L.A., MOCCELLIN, J. and MIWA, A.C.P. Nutrients and chlorophyll-a concentrations in tropical rivers of Ribeira de Iguape Basin, SP, Brazil. Acta Limnologica Brasiliensia, 2008, 20(2), 131-138.
ClARE, S., KROGMAN, N., FOOTE, L. and LEMPHERS, N. Where is the avoidance in the implementation of wetland lan and policy. Wetlands Ecology and Management, 2011, 19(2), 165-182. http://dx.doi.org/10.1007/s11273-011-9209-3.

CUNHA, D.G.F., BOTTINO, F. and CALIJURI, M.C. Land use influence on eutrophication-related water variables: case study of tropical rivers with differrent degrees of anthropogenic interference. Acta Limnologica Brasiliensia, 2010, 22(1), 35-45. http:// dx.doi.org/10.4322/actalb.02201005.

GRANADO, D.C. and HENRY, R. Changes in abiotic characteristics water in the Paranapanema River and three lateral lagoons at mouth zone of the Jurumirim Reservoir during the flood period. São Paulo, Brasil. Latin American Journal of Aquatic Research, 2012, 40(1), 79-89. http://dx.doi.org/10.3856/vol40issue1-fulltext- 8 .

HEIN, T., BARANYI, C., HERNDL, G.J., WANEK, W. and SCHIEMER, F. Allochthonous and autochthonous particulate organic matter in floodplains of the River Danube: the importance of hydrological connectivity. Freshwater Biology, 2003, 48(2), 220-232. http://dx.doi.org/10.1046/j.13652427.2003.00981.x.

HENRY, R. The connectivity of the Paranapanema River with two lateral lakes in its mouth zone into the Jurumirim Reservoir. Acta Limnologica Brasiliensia, 2005, 17(1), 57-69.

JONG, E.B.P., RAGAS, A.M.J., NOOTEBOOM, G. and MURSIDI, M. Changing water quality in the Middle Mahakam Lakes: Water quality trends in a context of rapid deforestation, mining and palm oil plantation development in Indonesia's Middle Mahakam Wetlands. Wetlands, 2015, 35(4), 733744. http://dx.doi.org/10.1007/s13157-015-0665-z.

JUNK, W.J., BAYLEY, P.B. and SPARKS, R.E. The flood pulse concept in river-floodplain systems. Canadian Special Publication of Fisheries and Aquatic Sciences, 1989, 106, 110-227.

KANSIIME, F., KATEYO, E., ORYEM-ORIGA, H. and MUCUNGUZI, P. Nutrient status and retention in pristine and disturbed wetlands in Uganda: management implications. Wetlands Ecology and Management, 2007, 15(6), 453-467. http://dx.doi. org/10.1007/s11273-007-9054-6.

KRUSCHE, A.V. and MOZETO, A.A. Seasonal variations in water quality of an oxbow lake in response to multiple short-time pulses of flooding (Jataí Ecological Station - Mogi-Guaçu River, Luiz Antonio, SP - Brazil) -. Anais da Academia Brasileira de Ciencias, 1999, 71(4), 777-790. PMid:10683673.

LEGENDRE, P. and LEGENDRE, L. Numerical Ecology. Amsterdam: Elsevier Science V. B., 1998, $871 \mathrm{p}$. 
LEWIS JUNIOR, W.M., HAMILTON, S.K., LASI, M.A. and RODRÍGUEZ, J.F. Ecological determinism on the Orinoco floodplain. Bioscience, 2000, 50(8), 681-692. http://dx.doi.org/10.1641/00063568(2000)050[0681:EDOTOF]2.0.CO;2.

MARGULES, C.R. and PRESSEY, R.L. Systematic conservation planning. Nature, 2000, 405(6783), 243-253. http://dx.doi.org/10.1038/35012251. PMid:10821285.

MITSCH, W.J. and GOSSELINK, J.G. Wetlands. New York: Wiley, 2007, $571 \mathrm{p}$.

MOCCELliN, J., CUNHA, C.A.G., FERRAZ, I.C. and CALIJURI, M.C. Comparação entre as características físicas e químicas da água dos rios Jacupiranga, Jacupiranguinha, Pariquera-Açu e Canha, Vale do Ribeira de Iguape, SP. In M.C. CALIJURI, A.C.P. MIWA and P.B. FALCO, orgs. Subsidios para a sustentabilidade dos recursos hidricos: um estudo de caso em sub-bacias do Baixo Ribeira de Iguape, São Paulo, Brasil. São Carlos: USP, 2009, $344 \mathrm{p}$.

NEIFF, J.J. Diversity in some tropical wetland systems of South America. In B. GOPAL, W.J. JUNK and J.A. DAVIS. Biodiversity in wetlands: assessment, function and conservation. Leiden: Backhuys Publishers, 2001, $353 \mathrm{p}$.

NEIFF, J.J. Ideas para la interpretación ecológica del Paraná. Interciencia, 1990, 15(6), 424-441.

NEIFF, J.J., POI DE NEIFF, A.S.G. and CASCO, $S$. The effect of prolonged floods on Eichhornia crassipes growth in Paraná River floodplain lakes. Acta Limnologica Brasiliensia, 2001, 13(1), 51-60.

PRINGLE, C.M. Hydrological connectivity and the management of biological reserves: a global perspective. Ecological Applications, 2001, 11(4), 981-998. http://dx.doi.org/10.1890/10510761(2001)011[0981:HCATMO]2.0.CO;2.

PRINGLE, C.M. What is hydrological connectivity and why is it ecologically important? Hydrological Processes, 2003, 17(13), 2685-2689. http://dx.doi. org/10.1002/hyp.5145.

REBELO, L.M., MCCARTNEY, M.P. and FINLAYSON, C.M. Wetlands of Sub-Saharan Africa: distribution and contribution of agriculture to livelihoods. Wetlands Ecology and Management,
2010, 18(5), 557-572. http://dx.doi.org/10.1007/ s11273-009-9142-x.

ROCHA, R.R.A. and THOMAZ, S.M. Variação temporal de fatores limnológicos em ambientes da planície de inundação do alto rio Paraná (PR/MS Brasil). Acta Scientiarium. Biological Sciences, 2004, 26(3), 261-271.

STATSOFT INC. StatSoft INC Statistica: data analysis software system: version 10 [online]. Tulsa: StatSoft, 2011 [viewed 13 Jan. 2016]. Available from: www. statsoft.com

THOMAZ, S.M., BINI, L.M. and BOZELLI, L.B. Floods increase similarity among aquatic habitats in river-floodplain systems. Hidrobiologia, 2007a, 579(1), 1-13. http://dx.doi.org/10.1007/s10750006-0285-y.

THOMAZ, S.M., CHAMBERS, P.A., PIERINI, S.A. and PEREIRA, G. Effects of phosphorus and nitrogen amended on the growth of Egeria najas. Aquatic Botany, 2007b, 86(2), 191-196. http:// dx.doi.org/10.1016/j.aquabot.2006.10.004.

THOMAZ, S.M., ROBERTO, M.C. and BINI, L.M. Caracterização limnológica dos ambientes aquáticos e influência dos níveis fluviométricos. In A.E.A.A. VAZZOLER, A.A. AGOSTINHO and N.S.A. HAHN, orgs. A planicie de inundação do alto rio Paraná: aspectos físicos, biológicos e socioeconômicos. Maringá: Eduem, 1997, 460 p.

TOCKNER, K., MALARD, F. and WARD, J.V. An extension of the flood pulse concept. Hydrological Processes, 2000, 14(16-17), 2861-2883. http://dx.doi.org/10.1002/10991085(200011/12)14:16/17<2861::AIDHYP124>3.0.CO;2-F.

TOCKNER, K., PENNETZDORFER, D., REINER, N., SCHIEMER, F. and WARD, J.V. Hydrological connectivity and the exchange of organic matter and nutrients in a dynamic river-floodplain system (Danube, Austria). Freshwater Biology, 1999, 41(3), 521-535. http://dx.doi.org/10.1046/j.13652427.1999.00399.x.

Received: 22 August 2013 Accepted: 31 March 2016 